ISSN 0103-5150

Fisioter. Mov., Curitiba, v. 28, n. 1, p. 69-76, Jan./Mar. 2015

Licenciado sob uma Licença Creative Commons

DOI: http://dx.doi.org.10.1590/0103-5150.028.001.A007

\title{
Implementation of physiotherapeutic shares in the prevention of diabetes complications in a Family Health Strategy ${ }^{1}$
}

\author{
Implementação de ações fisioterapêuticas na prevenção de \\ complicações do diabetes na Estratégia de Saúde da Família
}

\begin{abstract}
Ana Paula Coelho Figueira Freire ${ }^{[a]}$, Mariana Romanholi Palma ${ }^{[a]}$, João Carlos Aranha Lacombe ${ }^{[b]}$, Rodolpho Mauricio Leonardo Martins ${ }^{[b]}$, Renata Aparecida de Oliveira Lima ${ }^{[b]}$, Francis Lopes Pacagnelli ${ }^{[b] *}$
\end{abstract}

[a] Universidade Estadual Paulista (Unesp), Presidente Prudente, SP, Brazil

[b] Universidade do Oeste Paulista (Unoeste), Presidente Prudente, SP, Brazil

\section{Abstract}

Introduction: In the Family Health Strategy (FHS), the treatment of Diabetes Mellitus (DM) includes education and lifestyle change strategies. Physiotherapists have a key role in this health setting. Objectives: To implement actions of evaluation and guidelines for patients with type 2 DM who attend a Family Health Strategy (FHS), regarding diabetic foot and the practice of regular physical exercise in the control and prevention of the complications of Diabetes Mellitus. Methods: 17 individuals from an FHS were evaluated, with the following procedures: clinical and anthropometric parameters, inspection, a questionnaire on diabetic

\footnotetext{
1 The authors declare that there is no conflict of interest involving the present research.
}

\footnotetext{
* APCFF: Grad., e-mail: anapcff@hotmail.com MRP: Grad., e-mail: marianaromanholi@hotmail.com JCAL: Grad., e-mail: jc751@hotmail.com RMLM: Grad., e-mail: leozim_moreno@hotmail.com RAOL: MSc, e-mail: renatalima@unoeste.br FLP: PhD, e-mail: francispacagnelli@unoeste.br
} 
neuropathy, tests of vibratory and tactile sensitivity, muscle function, range of motion, functional analysis, questions about exercise practice and guidance regarding controlling blood glucose and foot care. Results: Deformities, dry skin, calluses, dehydration, ulceration, cracking and brittle nails were found. Peripheral neuropathy was not observed; tactile sensitivity was altered in the heel region and the vibratory sense was absent in $5 \%$ of individuals. A decrease in functionality of ankle movements was verified. Of the participants, $76 \%$ were sedentary, $24 \%$ knew about the benefits of practicing regular exercise, $25 \%$ had undergone a medical evaluation prior to performing physical exercise and, of these, $25 \%$ were supervised by a qualified professional. Discussion: The implementation of physiotherapy actions in diabetics from an FHS was important for highlighting the presence of risk factors for diabetic complications. Conclusions: Individuals attending the FHS need more information and programs for the prevention of diabetic complications.

Keywords: Physical Therapy. Diabetes Mellitus. Family health. Diabetic foot. Diabetic neuropathies.

\section{Resumo}

Introdução: Na Estratégia da Saúde da Família (ESF) o tratamento do Diabetes Mellitus (DM) inclui estratégias de educação e modificação do estilo de vida. Os fisioterapeutas vêm desenvolvendo papel fundamental nesse novo cenário de saúde. Objetivos: Implementar ações de avaliação e orientações para pacientes com DM tipo 2, quanto ao pé diabético e à prática regular de exercícios físicos no controle e na prevenção de complicações do DM, os quais frequentam uma Estratégia de Saúde da Família (ESF). Métodos: Foram avaliados 17 indivíduos de uma ESF, com os seguintes procedimentos: verificação de parâmetros clínicos e antropométricos, inspeção, questionário sobre neuropatia diabética, teste da sensibilidade tátil e vibratória, função muscular, amplitude de movimento, análise funcional, questionamentos sobre realização de exercícios, orientações sobre sua prática no controle glicêmico e orientações quanto aos cuidados com os pés. Resultados: Foram encontradas deformidades, pele ressecada, calos, desidratação, ulceração, rachaduras e unhas quebradiças. A investigação sobre neuropatia periférica não indicou sua presença; a sensibilidade tátil estava alterada principalmente na região do calcanhar e a sensibilidade vibratória estava ausente em $5 \%$ dos indivíduos. Verificou-se diminuição na funcionalidade em movimentos de tornozelo. Dos participantes, $76 \%$ eram sedentários e $24 \%$ conheciam os benefícios da prática regular de exercícios físicos; $25 \%$ dos indivíduos passaram por avaliação médica antes de realizar exercício físico, que era supervisionado por profissional habilitado em $25 \%$ dos casos. Discussão: A implementação de ações fisioterapêuticas nos diabéticos de uma EFS foi importante para destacar a presença de fatores de risco para complicações do diabetes. Conclusões: Os indivíduos da ESF necessitam de mais informaç̧̃es e programas para a prevenção de complicações do DM e apresentam alterações predisponentes a amputações e outras complicações.

Palavras-chave: Fisioterapia. Diabetes Mellitus. Saúde da família. Pé diabético. Neuropatias diabéticas.

\section{Introduction}

Diabetes Mellitus (DM) is a syndrome of multiple etiology and is expressed as one of the major public health problems in Brazil and worldwide (1). Diabetics represent about $30 \%$ of individuals who are hospitalized in intensive coronary care units, this being the cause of lower limb amputations and acquired blindness (2).

Diabetes Mellitus can be subdivided into different types, among them, type 2 , which accounts for $90 \%$ of cases of the disease. Patients with type 2 DM retain some capacity for endogenous excretion of insulin, however, the secretion levels of insulin are low compared to levels of body glucose and the magnitude of insulin resistance. Type $2 \mathrm{DM}$ is associated with a high-fat diet, obesity, and/or lack of regular physical activity (1).

The chronic complications of this disease include nephropathy, retinopathy, neuropathy, amputations, Charcot arthropathy and manifestations of autonomic dysfunction, which can lead to changes such as 
diabetic foot, characterized by lesions on the feet as a result of vascular and/or neurological alterations peculiar to DM. These complications require attention and care from health professionals who should promote the prevention, care and education of such conditions $(3,4)$.

The multiple complications of DM have resulted in high government costs in recent years, as well as the treatment of other diseases with chronic characteristics. Given the huge demand generated by various chronic conditions, the Family Health Strategy (FHS) was created in 1994, with the aim of working as a multidisciplinary team to develop health promotion, prevention and recovery of individuals on an ongoing basis in order to reduce the demand for hospital services $(5,6)$.

In the FSH the treatment of DM includes strategies for education and changes in lifestyle, such as smoking cessation, increased physical activity, reorganization of dietary habits and, if necessary, medication use. Physiotherapists are establishing a key role in this new field of health (7).

These professionals contribute to effective action at all levels of health care, including prevention of diabetic complications in individuals with DM through the implementation of guidelines regarding the care to be taken in the event of changes in sensation in the feet, blood glucose control, guidance and realization of frequent physical activities $(5,8)$.

As the new proposal for professional activities in the health sector of the FSH is very recent, there is a distinct shortage of information on this topic in the literature. It is therefore necessary to detail the new organization of professionals, in addition to defining more comprehensively the role of the physiotherapist in preventing DM in this scenario.

The aim of this study was to implement actions to evaluate and guide patients with type $2 \mathrm{DM}$, who attended an FHS, regarding diabetic foot and the practice of regular exercise to control complications of DM.

\section{Methods}

Sample

The study sample was composed of 17 individuals with a diagnosis of type 2 diabetes, 6 males and 11 females, who attended health centers in Presidente Prudente, São Paulo, Brazil. The evaluations were performed by scholars and teachers of the Physiotherapy course from the University.

\section{Protocol}

The patients underwent a comprehensive physical therapy evaluation which included personal data, information on the disease, results of recent examinations, blood pressure, body mass index, blood glucose and vital signs. In addition a foot inspection was performed, examining for ulcerations, corns, dehydration, brittle nails, fissures, cracks and deformities.

A validated questionnaire was applied for assessment of diabetic neuropathy (9). This questionnaire investigates symptoms, the presence of plantar ulcers in clinical history and functional difficulties, and when two or more points are obtained from a total of 15 , the diabetic patient is considered as neuropathic.

An evaluation of surface sensitivity was also performed, which covered five plantar areas: medial forefoot, lateral forefoot, midfoot, heel and hallux. A set of Semmes-Weinstein (SORRI Bauru ${ }^{\mathrm{TM}}$ ) nylon monofilaments was used. The monofilaments, from the finest to the thickest, were pressed on the plantar sites until they bent; the finest monofilament felt by the subject defined their level of tactile sensitivity. Two monofilaments were used: orange $(10.0 \mathrm{~g})$ and red magenta (300 g). For evaluation of the depth sensitivity and vibration, a Diapason $128 \mathrm{~Hz}$ was used (10).

Following this, motor function was analyzed through muscle function tests based on the protocols established by Kendall et al. (11), graduating from 0-5 and applied to the foot muscles (flexor and extensor of the toes and hallux), and the flexor (m. tibialis anterior) and extensor (m. triceps surae) muscles of the ankle.

Subsequently the amplitudes of articular ankle and foot movements (flexion and extension, inversion and eversion) were measured using a universal goniometer (12).

Shortly afterwards, a functional assessment of the lower limbs was carried out by means of the tests described in the literature (13) using the number of repetitions performed by the subject in each test as the scale for data analysis. The subject was requested, whilst standing upright, to raise the toes and forefoot from the ground (dorsiflexion), lift the heel off the ground (plantar flexion), raise the side of the foot from the floor (eversion) and lift the medial 
part of foot off the ground (inversion). The number of repetitions of these movements was counted over a period of 30 seconds. The guidance given to the patients was to repeat the movements the greatest number of times possible. For the eversion and inversion standing test, the following classifications were considered: no repetitions - nonfunctional; 1 to 2 repetitions - little functionality; from 3 to 4 repetitions - fairly functional; from 5-6 repetitions - functional. For the other tests of flexion and extension of the ankle and toes the following scale was used: no repetitions - nonfunctional; 1 to 4 repetitions - little functionality; from 5 to 9 repetitions - reasonably functional; and from 10 to 15 repetitions - functional.

After the functional assessments, several questions on physical activity were discussed such as whether or not the individual practiced regular exercise and knew the benefits of exercise for diabetics. For individuals who declared themselves physically active, a form was applied, designed with open and closed questions which addressed the type, frequency, duration and length of time of practicing physical activity; whether the individual received professional guidance for practice and from whom, whether the physical activity was supervised or not and by whom; whether there was intensity control during the physical activity and how this was controlled; whether a medical assessment had been carried out before the physical activity and what this had included; whether the individual felt some discomfort during the exercises and how they felt compared to the period when they did not practice physical activity.

After the evaluation, the subjects were instructed on the care of diabetic feet (hygiene, type of shoes and appropriate socks, hydration, recognition of signs caused by sensory changes) for the prevention of secondary complications and given recommendations for physical exercises for blood glucose control. Patients were instructed to perform some type of aerobic exercise a minimum of three times a week, such as walking at a moderate intensity until feeling slightly tired (14).

The present study was approved by the Committee for Ethics in Research of the University of Oeste Paulista (Unoeste), protocol No. 182.

Data were analyzed using descriptive statistics; the categorical variables were expressed as percentage, mean and standard deviation values.

\section{Results}

The study population had a mean age of $63.3 \pm 7.6$ years, and 10 participants were hypertensive. Clinical and anthropometric data are presented in Table 1.

In the evaluation of the feet through inspection, deformities (flat feet), dry skin, calluses, dehydration, ulceration, cracking and brittle nails were observed as demonstrated in Table 2.

In the investigation of the symptoms of peripheral neuropathy, the average score obtained in the applied questionnaire was $3.8 \pm 3.2$. Tactile sensitivity was abnormal in all plantar areas and the vibratory sense was absent in only $5 \%$ of individuals, as shown in Table 3.

In the tests of muscular function the individuals presented a mean score of 4 (overcoming the resistance of gravity with the additional force of the weight of the examiner's hand) in all muscle groups. This value, according to Kendall et al. (11), is graded as good muscle strength.

The range of the plantar flexion movement averaged $31.8^{\circ} \pm 6.1$, and the dorsiflexion $20^{\circ} \pm 2.6$.

Regarding the functionality of the feet, the individuals obtained functional and reasonably functional classifications in all movements; the correlation between movement and functional classification is presented in Table 4.

Of the 17 patients, $76 \%$ did not perform physical exercises (PE) and $24 \%$ were physically active. Of those who did not practice exercise, only $24 \%$ were aware of the benefits of PE. All the individuals who declared themselves practitioners of physical exercise had been instructed by the doctor to practice PE in order to control blood glucose and cardiovascular risk factors such as hypertension and dyslipidemia. Of these, 25\% had undergone a medical evaluation prior to commencing exercise, which consisted of an exercise test and a resting electrocardiogram.

All the individuals who performed physical exercise practiced walking, and only $25 \%$ of them were supervised by a qualified professional. All had performed the activity for more than one year, with a frequency of 3-5 times per week and an average duration of 60 minutes. In no cases was there any control on the intensity of the exercise, however, none of the subjects stated that they felt any kind of discomfort during the exercise, and when asked how they felt compared to the period when they were sedentary, they all stated that they felt better. 
Table 1 - Mean and standard deviation values of clinical and anthropometric parameters

\begin{tabular}{cc}
\hline Parameters & Mean \pm SD \\
\hline SBP $(\mathrm{mmHg})$ & $142.8 \pm 17$ \\
DBP $(\mathrm{mmHg})$ & $87.1 \pm 7.5$ \\
BMI $\left(\mathrm{Kg} / \mathrm{m}^{2}\right)$ & $27.6 \pm 4.6$ \\
Glycemia $(\mathrm{mg} / \mathrm{dl})$ & $154.5 \pm 52.2$ \\
HR $(\mathrm{bpm})$ & $73.2 \pm 6.6$ \\
Time of DM diagnosis (years) & $6.6 \pm 5.5$ \\
\hline
\end{tabular}

Note: SBP = Systolic Blood Pressure; DBP = Diastolic Blood Pressure; $\mathrm{BMI}=$ Body Mass Index; $\mathrm{HR}=$ Heart Rate; $\mathrm{DM}=$ Diabetes Mellitus.

Table 2 - Alterations observed in the inspection of the feet as a percentage relative to the number of individuals $(n=17)$

\begin{tabular}{cc}
\hline Alteration & Percentage \\
\hline Dry skin & $58 \%$ \\
Calluses & $41 \%$ \\
Brittle nails & $23 \%$ \\
Cracks & $15 \%$ \\
Dehydration & $11 \%$ \\
Deformities & $5 \%$ \\
Ulceration & $5 \%$ \\
\hline
\end{tabular}

Table 3 - Distribution in percentages of the stimulus discrimination of monofilaments in plantar areas in relation to the number of individuals $(n=17)$

\begin{tabular}{cccc}
\hline Plantar Area & & \multicolumn{2}{c}{ Monofilaments } \\
\cline { 4 - 4 } \cline { 3 - 4 } Medial forefoot & & $\mathbf{1 0 ~ g}$ & $\mathbf{3 0 0} \mathbf{~ g}$ \\
Lateral forefoot & & $80 \%$ & $24 \%$ \\
Mid-Foot & & $85 \%$ & $20 \%$ \\
Heel & & $67.5 \%$ & $15 \%$ \\
Hallux & $76 \%$ & $32.5 \%$ \\
\hline
\end{tabular}

Table 4 - Movement and functional category in relation to the percentage of individuals

\begin{tabular}{lc}
\hline $\begin{array}{l}\text { Movement and } \\
\text { Functional Classification }\end{array}$ & Percentage of individuals \\
\hline Eversion (F) & $99 \%$ \\
Eversion (RF) & $1 \%$ \\
Inversion (F) & $88 \%$ \\
Inversion (RF) & $22 \%$ \\
Dorsiflexion (F) & $88 \%$ \\
Dorsiflexion (RF) & $22 \%$ \\
Plantar flexion (F) & $88 \%$ \\
Plantar flexion (RF) & $22 \%$ \\
\hline
\end{tabular}

Note: $\mathrm{F}=$ Functional; $\mathrm{RF}=$ Reasonably Functional.

\section{Discussion}

Through the results obtained from the implementation of physiotherapy actions in diabetics at an FSH, the importance of highlighting the presence of risk factors for the development of diabetic complications, as well as working with actions that seek to limit the damage of this disease was observed. Furthermore, a high rate of comorbidities was noted, particularly hypertension.

Several of the variables analyzed presented results outside the normal rate, thus highlighting the importance of public health programs that provide control, prevention and care for chronic conditions.

The mean values obtained for both blood glucose (142.8 mg/dl) and blood pressure (142.8/87.1 $\mathrm{mmHg}$ ), are characterized as inappropriate regarding control. One of the factors that predisposes the onset of peripheral neuropathy is high values of and variations in the glycemic index, added to inadequate blood pressure values (15).

Another factor that contributes to the onset of neuropathy is the time since diagnosis. The population studied had a mean time since diagnosis of 6.6 years. Studies suggest that diabetic complications can appear after, on average, 11 years, however this data is variable and the emergence of such aggravating factors can vary from after between 5 and 43 years of diagnosis (16). 
Other concerning data were the average body mass index, which characterized the sample as overweight $\left(27.6 \pm 4.6 \mathrm{~kg} / \mathrm{m}^{2}\right)$, in addition to the high rate of sedentary individuals (76\%). All these associated risk factors; high levels of blood pressure, blood sugar and physical inactivity, may cause the studied population to be at potential risk of developing cardiovascular events and complications (17).

In a similar study involving 49 diabetics with a clinical diagnosis of peripheral neuropathy, hyperglycemia, overweight and inactivity of the population was also observed, where only $26.5 \%$ were physically active (18).

During the foot inspection, deformities, dry skin, calluses, foot dehydration, ulceration, cracking and brittle nails were found, which may be related to inappropriate use of shoes and lack of guidelines. Areas of plantar hyperpressure, associated with calluses are great predictors of ulcerative processes (13).

Physical exercise has been shown to be extremely important for diabetics as it improves glucose tolerance and insulin sensitivity. In addition, physical exercise can also slow or prevent tissue atrophy, improving tissue tolerance to bear loads and decreasing the chances of the emergence of plantar ulcers (18).

Given the importance of physical activity in the control and prevention of diabetic complications, the role of the physiotherapist is essential in the multidisciplinary team, of the present FHS scenario (5). This professional contributes to the appropriate prescription of physical activity in addition to promoting guidelines and care for various complications of diabetes.

According to the applied questionnaire, the mean score of the study population $(3.8 \pm 3.2)$ was not characterized as symptoms of peripheral neuropathy. This result could be related to the short time of diagnosis of DM in this population, since the longer the time of diagnosis, the greater the chances of developing such alterations (15).

In the evaluation of sensitivity, the majority of the individuals tested felt the $10 \mathrm{~g}$ monofilament, which is predicted in the literature as demonstrating preserved sensitivity (19). However, it was noted that the most affected area was the heel, which corroborates previously reported results and demonstrates the importance of guidelines to prevent injuries (17).

This finding can be attributed to the fact that the heel of the foot is the area that receives the greatest impact during locomotion activities, and therefore displays greater quantities of keratin and fat.
Furthermore, the heel receives sensory innervation from the sural nerve, which is one of the first to be affected in the development of diabetic neuropathy; thus, these added features may explain the decreased sensory perception in this region (20).

The majority of subjects evaluated did not present changes with respect to data on muscular strength, range of motion or functionality, which could also be related to the shorter time since diagnosis of the disease in the study sample when compared with other studies in the literature (17).

It is known that diabetic foot lesions result from the combination of two or more risk factors that act concomitantly and may be triggered by both intrinsic and extrinsic traumas, associated with peripheral neuropathy, peripheral vascular disease and biomechanical alterations (18).

Regarding the motor component, this contributes to atrophy and weakness of the small dorsal muscles, triggering an imbalance in the flexor and extensor tendons, deformities and alterations in gait. The autonomic component reduces or suppresses sweat on the feet, leaving them dry and predisposing them to cracks and fissures, in addition to triggering alterations in the venous artery $(3,21)$.

The study population presented a low incidence of ulcers during the study and none of the subjects had had previous amputation. However, despite being part of a health prevention program, the sample presented important sensory, motor and metabolic disorders, which put them at risk of developing ulcers and amputations $(3,22)$.

The DM educational process, regarding hyperglycemia, diabetic foot and its complications is paramount in preventing morbidity and mortality in this population. Studies state that such actions significantly reduce the appearance of ulcers and possible amputations after the development of educational programs. Thus, the work of the healthcare team is fundamental to achieve reductions in the prevalence of these complications $(3,15,23)$.

Based on the analyzed results of this study, the established presence of several risk factors associated with the formation of plantar ulcers highlights the importance of the healthcare team on intensifying education and prevention to control this scenario. Added to this fact, we highlight the necessity of continuous and prolonged care by professionals seeking a humanized and multidisciplinary treatment to benefit patients with these chronic conditions. 


\section{Conclusions}

In conclusion, individuals with type $2 \mathrm{DM}$, enrolled in a program of evaluation and prevention of the complications of this disease, presented risk factors for plantar ulcers development. Therefore, the creation and intensification of new educational strategies for prevention are suggested.

\section{References}

1. Sociedade Brasileira de Diabetes. Diretrizes da Sociedade Brasileira de Diabetes: 2009. 3. ed. Itapevi: A. Araújo Silva Farmacêutica; 2009.

2. Rodrigues ACS, Vieira GL, Torres HC. A proposta da educação permanente em saúde na atualização da equipe de saúde em Diabetes Mellitus. Rev Esc Enferm USP. 2010;44(2):531-7.

3. Duby JJ, Campbell RK, Setter SM, White JR, Rasmussen KA. Diabetic neuropathy: an intensive review. Am J Health Syst Pharm. 2004;61(2):160-73.

4. Fox CS, Coady S, Sorlie PD, Levy D, Meigs JB, D’Agostino $\mathrm{RB}$, et al. Trends in cardiovascular complications of diabetes. JAMA, 2004;292(20):2495-9.

5. Souza BW. Inclusão do fisioterapeuta no PSF: pela integralidade da atenção a saúde e reorientação do modelo assistencial. Fisioter Bras. 2007;11(84):113-22.

6. Alves VS. Um modelo de educação em saúde para o Programa Saúde da Família: pela integralidade da atenção e reorientação do modelo assistencial. Interface - Comunic, Saúde, Educ. 2005;9(16):39-52.

7. Torres HC, Amaral MA, Amorim MM, Cyrino AP, Bodstein R. Training of professionals, acting in primary health care, in Diabetes Mellitus education. Acta Paul Enferm. 2010;23(6):751-6.

8. Brasil ACO, Brandão JAM, Silva MON, Gondin Filho VC. O papel do fisioterapeuta do programa saúde da família do município de Sobral-Ceará. RBPS. 2005; 18(1):3-6.

9. American Diabetes Association. Standards of medical care in diabetes - 2010. Diabetes Care.2010;33 (Suppl 1):S11-61. doi: 10.2337/dc10-S011.
10. Feldman EL, Stevens MJ, Thomas PK, Brown MB, Canal N, Greene DA. A practical two-step quantitative clinical and electrophysiological assessment for the diagnosis and staging of diabetic neuropathy. Diabetes Care. 1994;17(11):1281-9.

11. Kendall FP, McCreary EK, Provance PG. Músculos: provas e funções. 4. ed. São Paulo: Manole, 1995.

12. Marques AP. Manual de Goniometria. São Paulo: Manole; 1997.

13. Mendonça SS, Morais JSA, de Moura MCGG. Proposta de um protocolo de avaliação fisioterapêutica para os pés de diabético. Fisioter Mov. 2011;24(2):285-98.

14. Arsa G, Lima L, Almeida SS, Moreira SR, Campbell CSG, Simões HG. Diabetes Mellitus tipo 2: aspectos fisiológicos, genéticos e formas de exercício físico para seu controle. Rev Bras Cineantropom Desempenho Hum. 2009;11(1):103-11.

15. Ochoa-Vigo K, Pace AE. Pé diabético: estratégias para prevenção. Acta Paul Enferm. 2005;18(1):100-9.

16. Sheffel RS, Bortolanza D, Weber CS, Costa LA, Canani LH, Santos KG, et al. Prevalência de complicações micro e macrovasculares e de seus fatores de risco em pacientes com diabetes melito do tipo 2 em atendimento ambulatorial. Rev Assoc Med Bras. 2004;50(3):263-7.

17. Sacco ICN, Sartor CD, Gomes AA, João SMA, Cronfli R. Avaliação das perdas sensório-motoras do pé e tornozelo decorrentes da neuropatia diabética. Rev Bras Fisioter. 2007;11(1):27-33.

18. Lyra R, Oliveira M, Lins D, Cavalcanti N. Prevenção do Diabetes Mellitus tipo 2. Arq Bras Endocrinol Metab. 2006;50(2):239-49. doi: 10.1590/ S0004-27302006000200010.

19. Ruschel AP, Milano D, Berlezi EM, Schneider RH. Condições vasculares periféricas do pé diabético em idosos. RBCEH. 2008;5(2):88-100.

20. Jirkovská A, Boucek P, Wosková V, Bartos V, Skibová J. Identification of patients at risk for diabetic foot: a comparision of standardized noninvasive testing with routine practice at community diabetes clinics. J Diabetes Compl. 2000;15:63-8. 
21. Menz HB, Lord SR, St George R, Fitzpatrick RC. Walking stability and sensoriomotor function in older people with diabetic peripheral neuropathy. Arch Phys Med Rehabil. 2004;85(2):245-52.

22. Holman N, Young RJ, Jeffcoate WJ. Variation in the recorded incidence of amputation of the lower limb in England. Diabetologia. 2012;55(7):1919-25. doi: 10.1007/s00125-012-2468-6.

23. Farjado C. A importância do cuidado com o pé diabético: ações de prevenção e abordagem clínica. Rev Bras Med Fam e Com. 2006;2(5):43-58.

Received: 04/19/2014

Recebido: 19/04/2014

Approved: $10 / 03 / 2014$

Aprovado: 03/10/2014 